\title{
SANKSI PIDANA (ISLAM) DALAM PERSPEKTIF FILSAFAT DAKWAH
}

\author{
Ahmad Gazali \\ UIN Antasari Banjarmasin
}

\begin{abstract}
Penal sanctions in Islam on more. Because the basic principle of criminal practice in Islamic justice is "better guilty, than punish innocent people". This paradigm may provide a philosophical explanation and Da'wah Islamiyah as a forgiving in the judicial process is much more severe, both for criminal actors and other communities. Therefore, the philosophical judgment of Da'wah Islamiyah against criminal law in Islam will be able to provide enlightenment in the judicial process in general.
\end{abstract}

Keywords: islamic crime, sense of justice and philosophical approach da'wah.

\section{Pendahuluan}

Al-Qur'an dan Al-Hadits merupakan sumber utama hukum Islam (Fiqh), kedua sumber inilah yang membedakan dengan sistem perundang-undangan lainnya yang lebih bertumpu pada hasil pemikiran manusia semata. Dalam diskursus tentang Islam, hukum Islam sering menjadi sentral perdebatan. Hal ini di karenakan hukum Islam tidak dapat dipisahkan dengan tujuan diturunkannya Islam sebagai agama (Ad Din) yang pada hakikatnya berkaitan dengan upaya pencapaian kemaslahatan kehidupan manusia dan alam semesta dalam kerangka menghadapi arus perubahan sosial.

Dalam perkembangannya hukum Islam sering berhadapan dengan realitas tuntutan umat Islam sebagai subjek maupun objek hukum Islam. Dari sinilah muncul persoalan terutama ketika hukum Islam tidak mampu beradaptasi dengan perubahan sosial dalam masyarakat. Bahkan dalam konfigurasi yang lebih ekstrem hukum islam menghadapi dilema antara merespon tuntutan perubahan sosial dengan tetap memberikan kemaslahatan pada manusia yang sering berpandangan negatif terhadap bentuk-bentuk sanksi pidana Islam dan kecendrungan untuk memelihara hakikat hukum Islam sebagai bagian yang transeden (ilahiah).

Kemaslahatan sebagai tujuan (maqasidu al-Syari'ah) akan dapat tercapai jika aturan hukum Islam tersebut disadari dan dipatuhi. Untuk dapat disadari dan dipatuhi berarti hukum Islam paling tidak harus bisa memberikan kontribusinya dalam dinamika perubahan sosial. Disinilah kemanfaatan hukum Islam perlu disosialisasikan (didakwahkan).

Sebagai makhluk sosial, manusia dalam aktifitasnya di berbagai lapangan kehidupannya tentunya mempunyai perbedaaan-perbedaan kepentingan yang dapat menimbulkan tindakan hukum dan merugikan orang lain.

Untuk memelihara kemaslahatan (ketertiban dan keadilan) dalam kehidupan manusia, syari'at juga mengatur sanksi dan memberikan hukuman terhadap pelanggaran hukum Islam, dan dalam penerapannya hukum Islam selalu membedakan sifat dan 
bentuknya sesuai dengan kualitas atau subtansi tindak pidana (Jarimah) yang di perbuat oleh si pelaku, sekalipun dari aspek coraknya memiliki kemiripan dan kesamaan. Untuk memahami secara filosofis apa makna dan subtansi sanksi pidana Islam di perlukan pembahasan yang komprehensive, makalah ini hanya merupakan sebagian dari keinginan pembuktian di maksud.

\section{Pembahasan}

\section{Beberapa Sanksi Pidana dalam Hukum Islam}

Landasan legistimasi pemnerlakuan hukuman atau sanksi adalah adanya peraturan atau hukum yang menjadi ukuran apakah seseorang melakukan tindak pidana atau belum. Di dalam Islam yang menjadi landasan tersebut adalah Al-Qur'an dan Sunnah Rasul yang diintrodusir oleh pemikiran Fukaha (hukum Islam/Fikh), Hukum Islam dijadikan landasan untuk menentukan ukuran tindakan pidana, karena dimungkinkan adanya ketidakjelasan pada Al-Qur'an mapun Hadits Rasul.

Sekalipun ancaman hukumannya sudah termaktub, tetapi mikanisme pelaksanaan hukuman atau penjatuhan sanksi masih memerlukan pemikiran (Al Fiqh) dan hanya dapat dilaksanakan oleh institusi pemerintahan (Ulil Amri) sehingga tidak semua orang dapat menjatuhkan sanksi terhadap seseorang yang melakukan tindak pidana (M. Muslehuddin, 1991: 72-73). Apalagi bila dilihat dari perspektif teori "lingkaran konsentres" yang menunjukan betapa erat dan terkaitnya hubungan antara agama, hukum dan negara (HM. Taher Azhary, 1992: 39-44).

Di antara sanksi pidana yang dijelaskan Al-Qur'an:

1. Wanita dan laki-laki yang belum nikah (bikir) berzina, hukumannya 100 kali pukulan cambuk (Q.S. An-Nur: 2). Bagi mereka yang muhsan (yang belum kawin) hukumannya dirajam sampai mati (Al-Hadits).

2. Seseorang dengan sengaja membunuh orang lain, hukumannya juga dibunuh (Q.S. Al- Maidah: 38). Dalam Ayat lain, seseorang yang bertindak dan menyebabkan orang lain hukumannya adalah memerdekakan budak yang muslim atau pembayaran fidyah lainnya.

3. Pencuri laki-laki dan wanita, hukumannya adalah potong tangan (Q.S. Al-Maidah: 38).

4. Orang yang menuduh orang lain berbuat zina, tetapi tidak mampu membuktikan tuduhannya itu sekurang-kurangnya 4 orang sanksi, hukumannya 80 kali cambuk (Q.S. An-Nur: 4).

5. Hukuman cambuk pernah dianalogikan Umar Ibn Khattab r.a. terhadap orang yang memalsukan cap Baitulmal dengan 100 kali cambukan (Sobhi Mahmasani, 1976: 225).

\section{Tinjauan Filososfis Dakwah dan Hikmah Sanksi dalam Pidana Islam}

Sanksi atau hukuman dalam pidana Islam mempunyai misi dakwah dan hikmah dalam proses rahmatan lil'alamin. Di antaranya:

1. Untuk mendukung dan memelihara syari'at dan hukum Islam (Wahbah Al Zuhaily, 1996: 189).

Di sini Syari'at dan hukum Islam bagaikan sebuah bangunan yang harus dipelihara. Apabila orang dengan bebas tanpa ada ancaman sanksi bila 
melanggarknya, maka syari'at akan kehilangan wibawanya sebagai sistem aturaan yang patut ditaati sebagai bagian dari dakwah islamiyah.

2. Merehabilitasi pelaku tindak pidana dan mencegah perluasan tindak pidana.

Rehabilitasi (penyadaran dalam istilah dakwah) diperlukan bagi mereka yang pernah berbuat tindak pidana agar masyarakat luas mau menerimanya sebagai anggota masyarakat yang baik. Ketika sanksi diberikan diharapkan dapat menyadarkan untuk menjadi manusia yang baik. Sebaliknya, lingkungan sosialnya dapat menjadikan hukuman atau sanksi itu sebagai pelajaran agar memberikan Side effect untuk tidak melakukan tindak pidana.

3. Untuk membentuk kesadaran masyarakat ( Marsum, 1984: 182-183).

Dimaksudkan membentuk kesadaran masyarakat adalah adanya prilaku masyarakat sebagai satu kesatuan sosial yang merasa bertanggungjawab untuk mencegah dari kemungkinana adanya tindak pidana.

4. Untuk menciptakan kemaslahatan bagi umat manusia.

Dalam tataran ontologi, lebih jauh tujuan pemberian sanksi dalam hukum Islam adalah untuk mencapai kemaslahatan sosial maupun perorangan, karena sanksi-sanksi itu ditetapkan oleh Allah SWT yang maha tahu dan maha adil ( A. Ahmad An Na'im, 1994: 214).

Kemaslahatan merupakan hakikat dari tujuan Syari'at (hukum) dan Dakwah Islam. Dari aspek manapun melihatnya, maka sebagai tujuan (maqasidu Asy-Syari'ah) adalah kemaslahatan umat Islam dan alam semesta. As-Shatibi dalam uraianya sampai pada kesimpulan tentang asal muasal hukum Islam yang satu (transendental), lebihlebih pada tujuan hukum Islam, yaitu kesejahteraaan dan kemaslahatan manusia (M. Khalid Mas'ud, 1995: 225).

Dengan demikian tujuan pemberian sanksi dalam hukum Islam atau syari'at apabila dilihat sampai pada hakikatnya, justru sangat berperikemanusiaan. Hukuman dalam syari'at jauh lebih berwawasan kemanusiaan dan futuristik serta mementingkan kesejahtraan sosial dan kedamaiaan serta lebih luas, karena Islam diturunkan adalah dalam rangka melimpahkan rahmat bagi seluruh alam semsta (Q.S. Al- Anbiya: 107). Sebab itu salah satu di antara sifat hukum Islam itu adalah bidimensional yakni mengandung kebaikan baik dari aspek kemanusiaan maupun aspek ketuhanan/ilahiyah (HM. Taher Azhary, 1992: 45-52).

Oleh karena itu semua bentuk sanksi yang diberlakukan pada dasarnya bermuara pada nilai-nilai ilahiyah yang menghendaki kemaslahatan manusia dan alam.

\section{Analisis Sanksi Pidana dalam Perspektif Filosofis Dakwah}

Dalam wacana filosofis, sanksi atau hukuman itu berada dalam dua tataran yaitu tataran epistemologis dan ontologis. Pada tataran epistemologis adanya sanksi tersebut lebih bernuansa duniawi (positivistis). Epistemolodis bergerak pada sumbu peran akal untuk menentukan sanksi melalui pembuktian, melalui penelitian terhadap latar belakang terjadinya tindakan pidana dan perlunya tindakan-tindakan lain yang mendukung ke arah terungkapnya kebenaran yang faktual. Seperti pembuktian adanya tindakan pencurian, adanya perzinahan dengan sanksi-sanksi dan pembunuhan dengan adanya perbuatan yang disengaja. Sesuai dengan kaidah hukum bahwa keputusan harus menurut kenyataan lahir. 
"Kita menghukum menurut kenyataan yang nampak (sesuai dengan pembuktian) dan Allah-lah yang menguasai yang tersembunyi" (Al-Hadits). Sekalipun secara realitas kemungkian bisa terjadi bahwa pembuktian itu direkayasa, tetapi makna pembuktian dalam hukum Islam tetap ingin menyentuh suatu kepastian hukum dalam logika kemanusiaan. Oleh sebab itu senada dengan kaidah ushul: "lebih baik membebaskan orang yang bersalah dari pada menghukum orang yang tidak bersalah". Prinsip ini mencerminkan adanya keinginan hukum Islam menebarkan kemasalahatan di tengah manusia, dan prinsip pemberian sanksi tersebut juga di landasi nilai etika yang lebih luhur dalam kaidah: "mencegah kemungkinan terjadinya kerusakan (mafsadat) lebih diutamakan dari pada mengambil manfaat".

Oleh sebab itu sekalipun perzinahan "telah terjadi" bila tidak disertai dengan kelengkapan 4 orang saksi, tuduhan tersebut dapat di batalkan. Dan bisa saja hukuman maksimal dengan cambuk ditiadakan lau di ganti dengan tahanan kurungan rumah sebagai alternatif pilihan sanksi bila kemaslahatan lebih mungkin didapatkan, karena adanya ayat tentang sanksi tahanan sebelum turunnya ayat tentang cambuk. Sekalipun ayat tersebut dikatakan dinasakh oleh ayat tentang cambuk.

Sanksi qisash, bisa saja tidak dilaksanakan, apabila ada pemafaan dari ahli waris atau keluarga korban yang kemudian diganti dengan diyat lain berupa pemberian sejumlah hewan (onta) atau berupa pembebasan budak. Hal ini jelas menunjukkan sebuah keadilan, kemanusiaan dan kemaslahatan. Bahwa qisash dilaksanakan dalam dimensi kesetaraan adalah untuk menunjukan rasa keadilan, artinya hukum Islam memberikan apresiasi terhadap keluarga korban dalam kesetaraan dan tidak terjebak dalam nuansa rasa iba sesaat hanya kepada si terhukum saat pelaksaan sanksi. Dan apabila si ahli waris memaafkan sipelaku tindak pidana qisash, tidak ada institusi kemanusiaan yang dapat mencegah atau menolak pemaaafan itu. Di sini jelas perikemanusiaan yang berdimensi dakwah islamiyah lebih diutamakan dalam hukum Islam. Prinsip kemanusiaan yang sama juga terefleksi dalam persyaratan kelengkapan 4 orang saksi dalam tindak pidana zina. Hakikatnya apabila 4 orang saksi telah melihat perbuatan zina berarti si pelaku selayaknya untuk dihukum, artinya perbuatan pelaku telah berada dalam dimensi hewani.

Sanksi potong tangan bagi pencuri tidak harus dilaksanakan, Umar Ibn Khattab r.a. menggurkan sanksi potong tangan dengan melihat latar belakangnya yang disandarkan pada nilai kemaslahatan dan kemanusiaan (Sobhi Mahmasari, 1976: 224). Keselarasan asas dalam hukum Islam seperti "jangan membuat melarat bagi dirinya dan juga orang lain" tercermin dalam sabda rasul: "tidak boleh hukum potong tangan (bagi pencuri) di dalam perjalanan". Atas dasar ini hukum Islam menghargai nilai kemaslahatan dan kemanusiaan di atas kepentingan kemanfaatan sisial psikologis. Dalam diskursus fiqh, istilah "tangan" memiliki alternatif makna, boleh jadi artinya kekuasaan atau peluang. Dalam perkembangan teknologi modern, tangan manusia dapat dibuat menggantikan tangan yang rusak. Apabila sanksi pemotongan tangan dilaksanakan secara tektual, yang dipotong tidak lebih dari peralatan yang dapat diganti setiap saat.

Bila itu terjadi, ayat Al-Qur'an akan kehilangan makna kontekstualnya. Menghindari hal itu, maka pemakaian kontekstualitas akan menjadi alternatif utama. Artinya sanksi potong tangan itu boleh jadi bermakna menutup kekuasaan dana peluang 
agar pencurian tidak pernah terjadi, secara filosofis sanksi tersebut berada dalam posisi peventif.

Persaksian yang menunjukan nilai kuantitas 4 orang, dalam hukum Islam dapat dimaknai sebagai upaya pembuktian yang harus akurat dan valid, boleh jadi dalam era modern sanksi itu tidak harus orang, tetapi boleh berupa sarana lain, yang pada dasarnya dapat menunjukan peristiwa tindak pidana secara meyakinkan.

Dalam tataran ontologis, adanya sanksi atau hukuman yang bersifat ukhrawi, internalistik dan nanti pada setiap tindak pidana atau pelanggaran terhadap syari'at dan hukum Islam. Di sini orang melakukan tindak pidana diancam siksa neraka yang pedih di akhirat kelak. Seperti ancaman terhadap orang yang membunuh sesama mukmin dengan sengaja, balasnnya adalah neraka jahanam, kekal ia di dalamnya (Q.S. An Nisa: 93).

Orang bisa saja merekayasa, sehingga terlepas dari sanksi hukum, tetapi secara hakiki hukuman itu Allah-lah yang menghakimi. Oleh sebab itu hukum Islam pada dasarnay bukanlah sistem pengekang aktifitas manusia, tetapi justru bertujuan membuatkan jalan yang menuju pada kesejahtraan dalam kesadaran sebagai subtnsi dakwah islamiyah.

\section{Simpulan}

Hukum Islam sebagaimana Yang diketahui selama ini masih diposisikan pada dua diskursus konsep: absolut dan otoriter, karena dikembangkan dari sudut pandang bahwa sumber hukum Islam adalah kehendak Tuhan Yang Maha Esa, yang muntlak dan tidak bisa berubah. Pandangan ini cendrung menyamakan hukum Islam dengan syari'at atau sama sekali tidak boleh dipersoalkan dalam kerangka ilmiah. Konsep kedua melihat hukum Islam sebagai sistem hukum yang lahir melalui proses ijtihad (pemikiran) untuk memahami kehendak-kehendak syari'at yang bersumbr dari AlQur'an dan Sunnah, dan dia hadir dalam upaya memecahkan persoalan-persoalan yuridis dalam masyarakat (Nizam al-Din Abu Hamid, 1984: 9-10). Dengan demikian dalam perkembangannya, intervensi filosofis di dalamnya adalah suatu keniscayaan apalagi terkait dengan dinamika sosial.

Munculnya persoalan krusial dalam implementasinya lebih disebabkan oleh pendekatan yang terlalu kaku terhadap sumber-sumber hukum Islam (terkstualistik) yang ingin selalu diwariskan dari 14 abad yang lalu ke sana sini, hal inilah yang kemudian memunculkan persoalan dalam pandangan orang-orang filosofis bahwa hukum Islam sering ketinggalan dibandingkan dengan lajunya arus perubahan sosial yang sangat memerlukan pengayoman hukum Islam secara kontekstual dan futuristik. Pembahasan makalah ini hanya merupakan langkah awal dari sebuah perjalanan panjang dan perjalanan panjang mesti harus di mulai dengan langkah awal.

\section{Daftar Pustaka}

An Na'im, Abdullah Ahmed, Toward An Islamic Reformation Civil Liberties Human Right and International Law, Terj, LKIS, Yogyakarta, 1994.

AL Zuhaily, Wahbah, Al-Qur'an Al Karim: Bunyatuhu At Tasyri'at Wa Khashaishuku al Hadhriyat. Terj, Risalah Gusti, Surabaya, 1996. 
Azhary, M. Taher, Negaraa Hukum, Studi Tentang Prinsip-Prinsipnya Dilihat Dari Segi Hukum Islam, Implementasi pada Periode Madinah dan Msa Kini. Bulan Bintang, Jakarta. 1992.

Djazuli, A., Fiqh Jinayat (Upaya Menanggulangi Kejahatan Dalam Islam), PT. Rajawali Grafindo Persada, Jakartaa, 1997.

Mersum, Jinayat (Hukum Pidans Islam), UII, Yogyakarta, 1984.

Muslehuddin, Muhammad. Philosophy Of Islamic Law, Terj, PT. Tiara Wacana Yogya, Yogyakarta, 1991.

Ma'ud, Muhammad Khalid, Islamic Legal Philosophy A Studi Of Abu Ishaq al Shatibi S Life and Thought, Terj, Al-Ikhlas, Surabaya, 1995.

Mahmasani, Sobhi, Falsafatu At Tasyri Fi al-Islam, Terj, PT. Al Ma'arif, Bandung, 1976. 